\title{
Trace elements' uptake and antioxidant response to excess of manganese in in vitro cells of sensitive and tolerant wheat
}

\author{
Apolonia Sieprawska ${ }^{1} \cdot$ Maria Filek $^{1} \cdot$ Anna Tobiasz $^{2} \cdot$ Stanisław Walas $^{2} \cdot$ \\ Danuta Dudek-Adamska ${ }^{2} \cdot$ Emilia Grygo-Szymanko $^{2}$
}

Received: 31 July 2015/Revised: 5 January 2016/Accepted: 11 January 2016/Published online: 1 February 2016 (C) The Author(s) 2016. This article is published with open access at Springerlink.com

\begin{abstract}
Manganese, a microelement important for plant metabolism, when accumulated at higher doses, may act as a stress factor. Such action of this element is not fully recognized and is currently being intensively studied. The influence of manganese, at high (1,2 and $3 \mathrm{mM})$ concentrations, on the induction of oxidative stress in wheat cells was studied under in vitro conditions. Calli of two wheat cultivars, different in terms of stress tolerance, were cultured for 7 days on Murashige-Skoog media with or without auxin (2,4-D) and with additional Mn supplementation. Changes of malondialdehyde (MDA) concentration and the activity of enzymes (SOD, CAT and POX) involved in oxidative response as well as the accumulation of $\mathrm{Mn}$ and elements essential for plant development (Mn, $\mathrm{Mg}, \mathrm{S}, \mathrm{Ca}, \mathrm{K}, \mathrm{P}, \mathrm{Na}, \mathrm{Zn}, \mathrm{Mo}, \mathrm{Cu}, \mathrm{Fe}$ ) were detected. Moreover, proline and carbohydrate contents were determined to check the induction of osmotic stress. An increase of lipid peroxidation (expressed by MDA content), induced by ROS generation, was smaller in the tolerant ('Parabola') cultivar than in the sensitive one ('Raweta'). The activation of antioxidative enzymes was more effective in the cells of tolerant wheat, where a lower quantity of Mn was accumulated. Mn uptake was correlated with a decrease of an amount of almost all the investigated elements. Auxin
\end{abstract}

Communicated by R. Baczek-Kwinta.

Apolonia Sieprawska

apolonia.sieprawska@gmail.com

1 Department of Biochemistry, Biophysics and Biotechnology, Institute of Biology, Pedagogical University, Podchorążych 2, 30-084 Kraków, Poland

2 Department of Analytical Chemistry, Faculty of Chemistry, Jagiellonian University, Ingardena 3, 30-060 Kraków, Poland presence in the culture media accelerated the stressogenic effect of Mn.

Keywords Manganese $\cdot$ Oxidative stress $\cdot$ In vitro cells · Wheat $\cdot$ Micro- and macroelements

\section{Introduction}

Manganese (Mn) is an essential trace element required for the growth and survival of most, if not all, living organisms. It may exist in various oxidation states as $\mathrm{Mn}^{1+}$, $\mathrm{Mn}^{2+}, \mathrm{Mn}^{3+}, \mathrm{Mn}^{4+}, \mathrm{Mn}^{6+}$ and $\mathrm{Mn}^{7+}$; however, the most dominant forms found in biological systems are $\mathrm{Mn}^{+2}$, $\mathrm{Mn}^{+3}$ and $\mathrm{Mn}^{+4}$ (Marschner 2012). For plants, the bioavailability of this element is dependent on the $\mathrm{pH}$ of the soil. At low $\mathrm{pH}$ (till about 5), Mn is uptaken mainly as divalent cations, whereas at higher $\mathrm{pH}$ values, $\mathrm{Mn}^{3+}$ and $\mathrm{Mn}^{4+}$ represent the most prevalent forms, usually not absorbed by plants (Rengel 2000). In addition, the participation of $\mathrm{Mn}^{2+}$ in soils is enhanced under iron $(\mathrm{Fe})$ and zinc ( $\mathrm{Zn}$ ) deficiency (Cohen et al. 1998). It is assumed that Mn may be taken up by plants via the same transporters as other divalent cations, such as iron (Fe), zinc ( $\mathrm{Zn})$, copper $(\mathrm{Cu})$ and cobalt $(\mathrm{Co})$ (Xia et al. 2010). Plasma membrane $\mathrm{Ca}$ channels could also be involved in the transport of $\mathrm{Mn}$ (Pittman 2005).

In cells, $\mathrm{Mn}$ is a component of metalloenzymes engaged in the antioxidant defense system, such as superoxide dismutase (MnSOD). As a component of oxidizing complex in PSII, it takes part in the photosynthesis process, which catalyzes the oxygen evolvement (Merchant and Sawaya 2005; Todorović et al. 2009). In addition, Mn is required for carbohydrate, lipid and protein biosynthesis (Marschner 2012). As an activator of enzymes involved in auxin 
synthesis, it is also essential for cell division and elongation (Seresinhe 1996).

Manganese deficiency is a widespread problem, typically more pronounced in cool and wet conditions (Alloway 2008). Numerous crops, including wheat, barley and oats, are sensitive to Mn deficiency, as revealed by high decline in yield. The reduced Mn content in the cells substantially impairs photosynthesis, resulting in a marked decrease in soluble sugar concentration in various parts of plants. The usual level of this essential element in the leaves is in the range from about 30 to $500 \mathrm{mg} / \mathrm{kg}$ of dry weight, depending on the genotype (Millaleo et al. 2010). Some plant species are able to tolerate even higher amounts of $\mathrm{Mn}$ - up to $12,000 \mathrm{mg} / \mathrm{kg}$ (Reeves 2006). However, the excess of $\mathrm{Mn}$ is commonly extremely toxic to the majority of plant cells, inducing oxidative stress through the production of reactive oxygen species (ROS) in the Fenton reaction (Lynch and St Clair 2004) or by direct transfer of electrons in a single reaction (Demirevska-Kepova et al. 2004; Boojar and Goodarzi 2008). Mn at the toxic level exchanges other essential metal ions in the active centers of enzymes or binds to functional groups (sulfhydryl, phosphate or histidyl groups) (Elstner et al. 1988; Migocka and Klobus 2007). Under conditions of Mn excess, apoplastic deposition of its oxidized forms occurs and it is suggested that peroxidases are involved in this reaction (FechtChristoffers et al. 2003). Besides these enzymes, other antioxidant enzymes, such as superoxide dismutase (SOD) and catalase (CAT), may be engaged in the scavenging system, minimizing cellular damage caused by ROS (Chen et al. 2005; Shi et al. 2006). Higher activities of antioxidant enzymes in response to Mn excess were found in woody plants (Lei et al. 2007), herbs such as white clover (Trifolium repens L.) and in ryegrass (Lolium perenne L.) (Rosas et al. 2007; Mora et al. 2009). However, the changes in the activity of these enzymes were dependent on the plant tolerance to oxidative stress. In sensitive plants, a decrease of antioxidative enzymes activity (especially SOD), as a result of protein damages by ROS, was registered (Babitha et al. 2002; Perveen et al. 2011).

High Mn concentrations stimulate cytotoxic effects in cell structure causing extensive modifications in the content of cytoplasmic components and plasma membranes (Todorović et al. 2009). An increase of membrane lipid peroxidation is accepted as an indicator of oxidative stress intensity (Taulavuori et al. 2001; Filek et al. 2012). It was also found that Mn excess can inhibit the uptake of other essential elements, such as calcium $(\mathrm{Ca})$, magnesium $(\mathrm{Mg})$, iron $(\mathrm{Fe})$ and phosphorus $(\mathrm{P})$ due to the similarity of ionic size or binding strength in ligands (Marschner 2012; Millaleo et al. 2013). Alam et al. (2001) indicated an association between $\mathrm{Mn}$ toxicity and a decrease of $\mathrm{Ca}$ concentration in barley. In later studies, Alam et al. (2005,
2006) showed that Mn toxicity could be repressed by high concentrations of $\mathrm{Ca}$ and potassium (K), leading to decrease in Mn absorption and translocation in plants. The correlation between $\mathrm{Mg}$ and $\mathrm{Mn}$ is connected with the possibility of replacement of one element by the other in many cellular processes (Socha and Guerinot 2014). Moreover, Ashok et al. (2009) revealed that sulfur (S) application may increase $\mathrm{Mn}$ uptake. Despite the growing interest in the toxic effects of Mn in plants, and demonstrating the relationship between its absorption and the accumulation of some elements, there is no comprehensive research on the impact of $\mathrm{Mn}$ on the absorption of all micro- and macroelements, necessary for proper growth and development of plants, particularly in terms of phenotypic tolerance to environmental stresses.

The aim of this study was to check whether the wheat plant cells, differing in their tolerance to drought stress, also differ with respect to sensitivity to $\mathrm{Mn}$ at toxic levels and accumulation of other elements, important in physiological processes. Both drought and metal stresses usually induce a reduction of water potential in plants (Łabanowska et al. 2013; Upadhyaya et al. 2013). In the current experiments, changes in the activity of antioxidant enzymes were adopted as indicators of Mn stress action. Moreover, the synthesis of proline and carbohydrates, substances responsible for osmotic protection, was analyzed. An increased accumulation of these substances in plants has been observed in reaction to a wide range of abiotic and biotic stresses (Hare and Cress 1997; Mohammadkhani and Heidari 2008; Marcińska et al. 2013). The influence of Mn on transport of other essential micro- and macroelements as an important step in the recognition of its toxic effect was also studied.

The experiments were made in in vitro conditions on callus cells cultured on media with and without synthetic auxin (2,4-dichlorophenoxyacetic acid; 2,4-D) to compare the effects of $\mathrm{Mn}$ in cells with a potentially non-induced and induced regeneration (Filek et al. 2009). The results of the experiments will allow demonstrating the role of auxins in the plant tolerance to manganese stress. According to Santandrea et al. (1997, 1998), callus cells can serve as a suitable model system to observe metal-toxic reactions including Mn effects.

\section{Materials and methods}

\section{Plant material}

Spring wheat of two cultivars: tolerant ('Parabola') and sensitive ('Raweta') were obtained from the Polish Plant Breeding Stations (Radzików and Strzelce, Poland). The differences in stress tolerance between the used genotypes 
were indicated in our earlier studies (Grzesiak et al. 2013; Sieprawska et al. 2014). Seeds, after sterilization and germination, were put in pots with a mixture of soil:peat:sand $(3: 2: 1 ; \mathrm{v} / \mathrm{v} / \mathrm{v})$ and cultured in a greenhouse at control conditions: temperature $\left(20 / 17{ }^{\circ} \mathrm{C}\right.$; day/night), and light [16/8 h day/night photoperiod, $400 \mu \mathrm{mol}$ (quantum) $\mathrm{m}^{-2} \mathrm{~s}^{-1}$ light]. When the first anthers were developed, immature embryos were isolated and prepared for in vitro cultures, as described earlier (Filek et al. 2009). Non-embryogenic calli, cultured on Murashige and Skoog (MS) medium (1962) supplemented with $2 \mathrm{mg} / \mathrm{ml}$ 2,4-D, were chosen as the plant material.

In the preliminary experiments with various $\mathrm{Mn}$ $\left(\mathrm{MnSO}_{4}\right)$ concentrations applied to the culture media (200 $\mu \mathrm{M}-3 \mathrm{mM})$, the stressogenic effect of Mn was determined on the basis of an increase in lipid peroxidation of callus cells. Based on this analysis, 1, 2 and $3 \mathrm{mM} \mathrm{Mn}$ were chosen for further study. Seven-day calli, cultured on MS media without 2,4-D (0) and with 2,4-D (2), supplemented with $\mathrm{MnSO}_{4}$, were collected. For each of the studied condition, 12 Petri dishes were prepared. After Mn treatment, calli were frozen in liquid $\mathrm{N}_{2}$ and stored at $-80{ }^{\circ} \mathrm{C}$. Calli cultured on media without $\mathrm{Mn}$ served as a control.

\section{Biochemical analysis}

\section{Malondialdehyde (MDA) determination}

MDA content was used as an indicator of lipid peroxidation. Calli were homogenized with $0.5 \%$ trichloroacetic acid (TCA) and MDA concentration was determined via changes in thiobarbituric acid (TBA) concentration, according to the procedure described in detail by Dhindsa et al. (1981) and in our earlier studies (Tobiasz et al. 2014).

\section{Enzyme extraction and assays}

Enzymes were analyzed after the initial extraction of about $1 \mathrm{~g}$ of callus in $1.5 \mathrm{~cm}^{3}$ of $0.1 \mathrm{M}$ potassium phosphate (KP) buffer containing $2 \mathrm{mM} \alpha$-dithiothreitol, $0.1 \mathrm{mM}$ EDTA, $1.25 \mathrm{mM}$ polyethylene glycol and ethylenediaminetetraacetic acid (EDTA) (pH 7.8). Then, the samples were centrifuged at $14,000 \times g$ for $30 \mathrm{~min}$ and the supernatant purified on a PD10 column (Amersham Biosciences, Sweden).

Superoxide dismutase (SOD, EC 1.15.11) activity was registered at $\lambda=595 \mathrm{~nm}$ (BiochromUltrospec II, LKB, Sweden) by a modified method of McCord and Fridovich (1969), in which one unit of SOD activity was expressed as the amount of enzyme required to cause $50 \%$ inhibition of cytochrome $\mathrm{c}$ in a system of xanthine and xanthine oxidase. The activity of catalase (CAT, EC 1.11.16) was detected by a modified method of Aebi (1984), at $\lambda=240 \mathrm{~nm}$, with an initiation mixture of $0.03 \mathrm{mM} \mathrm{H}_{2} \mathrm{O}_{2}$ in $\mathrm{KP}$ buffer. Peroxidase (POD) activities were measured at $\lambda=485 \mathrm{~nm}$ by a modified method of Lück (1965) as the amount of products of reaction with $1 \%$ phenylenediamine in the presence of $0.03 \mathrm{mM} \mathrm{H}_{2} \mathrm{O}_{2}$ in KP buffer. All enzymes' activities were analyzed 60 and $120 \mathrm{~s}$ after the initiation of reaction using the KINLAB software for determination of the reaction kinetics.

\section{Proline analysis}

Proline was identified after homogenization in $3 \%$ aqueous sulfosalicylic acid and quantitatively determined by spectrometric technique (Evolution 201, Thermo Scientific) with ninhydrin reagent (1\% in $60 \%$ acetic acid), as described by Bates et al. (1973) with Grzesiak et al. (2013) modification.

\section{Soluble carbohydrate content}

The content of soluble sugars was determined according to Janeczko et al. (2010) with same modifications. Samples (about $1 \mathrm{~g}$ ) were homogenized with $3 \mathrm{~cm}^{3} 80 \%$ (v:v) ethanol and centrifuged at $5000 \times g$ for $10 \mathrm{~min}$. The supernatant was mixed with anthrone reagent $(0.2 \mathrm{~g}$ anthrone in $1000 \mathrm{~cm}^{3} 72 \% \mathrm{H}_{2} \mathrm{SO}_{4}$ ) and then heated at $98{ }^{\circ} \mathrm{C}$ for $10 \mathrm{~min}$. After cooling down to room temperature, the content of carbohydrates was determined spectrometrically (RayLeigh 1601) at $\lambda=625 \mathrm{~nm}$ and calculated according to the standard curve [glucose (Sigma Aldrich)].

\section{Determination of micro- and macroelements}

The concentration of elements in the calli was determined by atomic spectrometry techniques after their microwave digestion with the use of the Anton Paar 3000 system. Prior to the analysis, ca. $1.2 \mathrm{~g}$ portions of thawed samples (washed out from vials with $1 \mathrm{~cm}^{3}$ of deionized water) were digested with $6 \mathrm{~cm}^{3}$ of concentrated nitric acid, according to a two-step procedure for eight samples. In this procedure, the ramp time, up to a maximum energy of $1100 \mathrm{~W}$, and the hold time were 10 and $30 \mathrm{~min}$, respectively. The whole process was pressure controlled: the pressure $p$ rate was set at $0.5 \mathrm{bar} / \mathrm{s}$, while the maximum pressure was 60 bar. The digested solutions were diluted with deionized water up to $10 \mathrm{~cm}^{3}$.

Microelement isotopes: Fe57, Zn68, Cu63 and Mo98 were determined by inductively coupled plasma mass spectrometry (ICP MS) technique using Elan DRC-e (Perkin Elmer), applying nebulizer gas flow of $0.9 \mathrm{~cm}^{3} / \mathrm{min}$ and ICP RF power of $1100 \mathrm{~W}$ in samples after 25 -fold dilution. 
Macroelements were determined by an inductively coupled plasma optic emission spectrometer ICP OES Optima 2100 (Perkin Elmer) using three different methods: (a) $\mathrm{S}(181.975 \mathrm{~nm}), \mathrm{P}(213.617 \mathrm{~nm})$ in axial plasma observation mode and high argon flow through the monochromator system; (b) $\mathrm{Mn}$ (259.372 nm), $\mathrm{Na}$ (589.592 nm), Mg (285.213 nm), Fe (238.204 nm), Ca $(317.933 \mathrm{~nm})$ in axial plasma observation mode; and c) $\mathrm{K}$ $(766.490 \mathrm{~nm})$ in radial observation mode. For all analyses, digests were diluted four times, instead of $\mathrm{K}$ determination, which required 25 times dilution and addition of cesium nitrate as a spectral buffer in a concentration of $1 \mathrm{~g} / \mathrm{dm}^{3}$.

The final element concentrations in the calli were recalculated based on the average content of water $(93.9 \%)$.

\section{Statistical analysis}

Data were presented as mean $\pm \mathrm{SE}$. The experiments were repeated at least three times, and each experiment included 12 repetitions (calli from 12 Petri dishes) for each treatment. Data from different Mn treatments were analyzed statistically using the SAS ANOVA procedure. Comparisons of the means were done using Duncan's multiple range test with PC SAS 8.0. Differences with $p$ values lower than 0.05 were considered as significant. The correlations between all the investigated elements and biplot analysis were used for the classification of wheat calli (tolerant and sensitive varieties), based on the content of micro- and macroelements, after Mn treatment.

\section{Results}

The stressogenic effect of Mn treatment on callus cells was expressed by changes of MDA concentrations (Fig. 1a). For calli of both 'Parabola' and 'Raweta', for cells cultured on MS media without 2,4-D (0), a significant increase of MDA content was observed at higher (2 and $3 \mathrm{mM}) \mathrm{Mn}$ levels, whereas for calli cultured on media with 2,4-D the increase of this parameter was detected even at $1 \mathrm{mM}$ doses of Mn. Calli of 'Raweta' cultured on media in the presence of auxin (R2) reacted especially well, showing about $30 \%$ rise of MDA, whose level remained independent of Mn concentration. For 'Parabola' calli, an increase of MDA concentration was smaller at 1 and $2 \mathrm{mM} \mathrm{Mn}$ doses, reaching about $20 \%$ at $3 \mathrm{mM} \mathrm{Mn}$ in the media.

Changes in SOD activity were also dependent on the 2,4-D presence/absence in the media (Fig. 1b). For media without hormone, the highest increase of SOD activity was reached at $1 \mathrm{mM} \mathrm{Mn}$ addition. Other Mn doses resulted in subsequent decrease of SOD activity with increasing Mn concentration. More significant changes were detected for
'Parabola' calli. In the presence of 2,4-D in the media, a decrease of SOD activity was noted even at $1 \mathrm{mM} \mathrm{Mn}$ supplementation and was most evident for 'Raweta' calli (especially at the lowest Mn content). Alterations in catalase activity resembled those found for SOD, and similar relationships between the hormone presence and $\mathrm{Mn}$ treatment were observed for both 'Parabola' and 'Raweta' calli (Fig. 1c). POX activity in 'Parabola' cells was independent of 2,4-D presence and increased at $1 \mathrm{mM}$ Mn dose, with subsequent decrease at higher Mn content in the media (Fig. 1d). POX activity in 'Raweta' cells was already decreased at $1 \mathrm{mM} \mathrm{Mn}$ in both 0 and 2,4-D media.

The proline content was generally smaller in 'Parabola' cells in comparison to 'Raweta' (Fig. 1e). About $20 \%$ increase of this substance was found at $1 \mathrm{mM} \mathrm{Mn}$ concentration in the media (without 2,4-D). In all other treatments, a decrease of proline content was recorded; however, it was higher for calli cultured on media with 2,4D. For 'Raweta' calli grown on media with hormone supplementation, about 2.5-fold increase of proline level (in comparison to control) was observed at $1 \mathrm{mM} \mathrm{Mn}$ and remained higher even at the highest used Mn treatment. A smaller increase of proline amount was detected in 'Raweta' calli cultured on media without 2,4-D.

The total content of soluble carbohydrates was decreased in calli of both wheat genotypes cultured in the presence and absence of the hormone for all Mn supplementations (Fig. 1f). Exceptions were 'Parabola' calli grown on MSO media, in which case at 1 and $2 \mathrm{mM} \mathrm{Mn}$ doses, carbohydrate levels were almost equal to those detected for control.

The Mn content in the cells of 'Parabola' genotype cultured on control media (without additional Mn supplementation) was lower than in 'Raweta' cells. The 2,4-D presence slightly increased the accumulation of this element in both studied genotypes (Table 1). An increase of Mn amount in the media resulted in its elevated uptake in 'Parabola' cells cultured on both 0 and 2,4-D media. In 'Raweta' cells, the application of $1 \mathrm{mM} \mathrm{Mn}$ led to an increase of $\mathrm{Mn}$ absorption in calli grown on media with 2,4-D, whereas 2 and $3 \mathrm{mM}$ Mn doses resulted in a further rise of $\mathrm{Mn}$ accumulation with smaller differences in its level.

In the control 'Parabola' cells in comparison to 'Raweta', higher amounts of $\mathrm{Fe}, \mathrm{Zn}$ and $\mathrm{Mo}$ and smaller amounts of $\mathrm{Cu}$ were found (Fig. 2). Under Mn treatment, a decrease of all the investigated microelements was observed. The exceptions were contents of $\mathrm{Zn}$ (Fig. 2b) in 'Raweta' calli (on 0 media) and Mo (Fig. 2d) in 'Raweta' calli (in the presence of 2,4-D), where the levels of these elements were comparable to the control.

Considering macroelements' accumulation in the investigated control cells, 'Parabola' absorbed S, P and Mg 
A
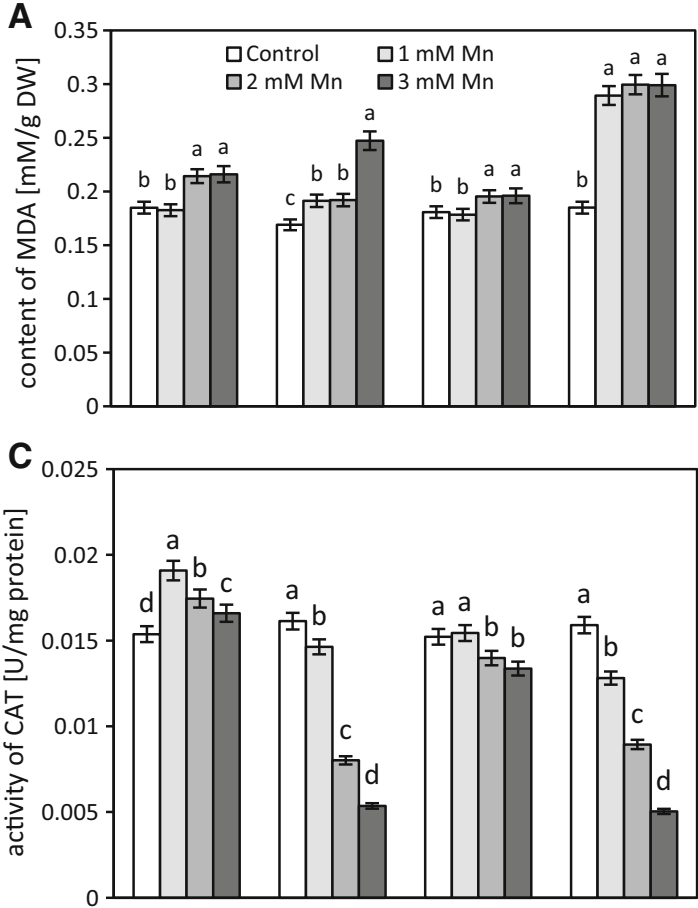

E

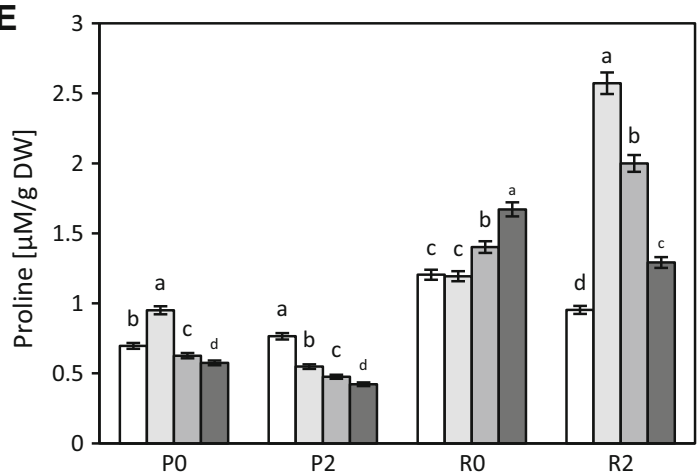

Fig. 1 Malondialdehyde (MDA) content (a); superoxide dismutase $(\mathrm{SOD} ; \mathbf{b})$, catalase (CAT; $\mathbf{c}$ ) and peroxidase (POX; $\mathbf{d})$ activity; proline (e) and carbohydrate (f) content in calli of wheat cv. Parabola (P) and cv. Raweta (R) cultured in Murashige and Skoog media without 2,4-D
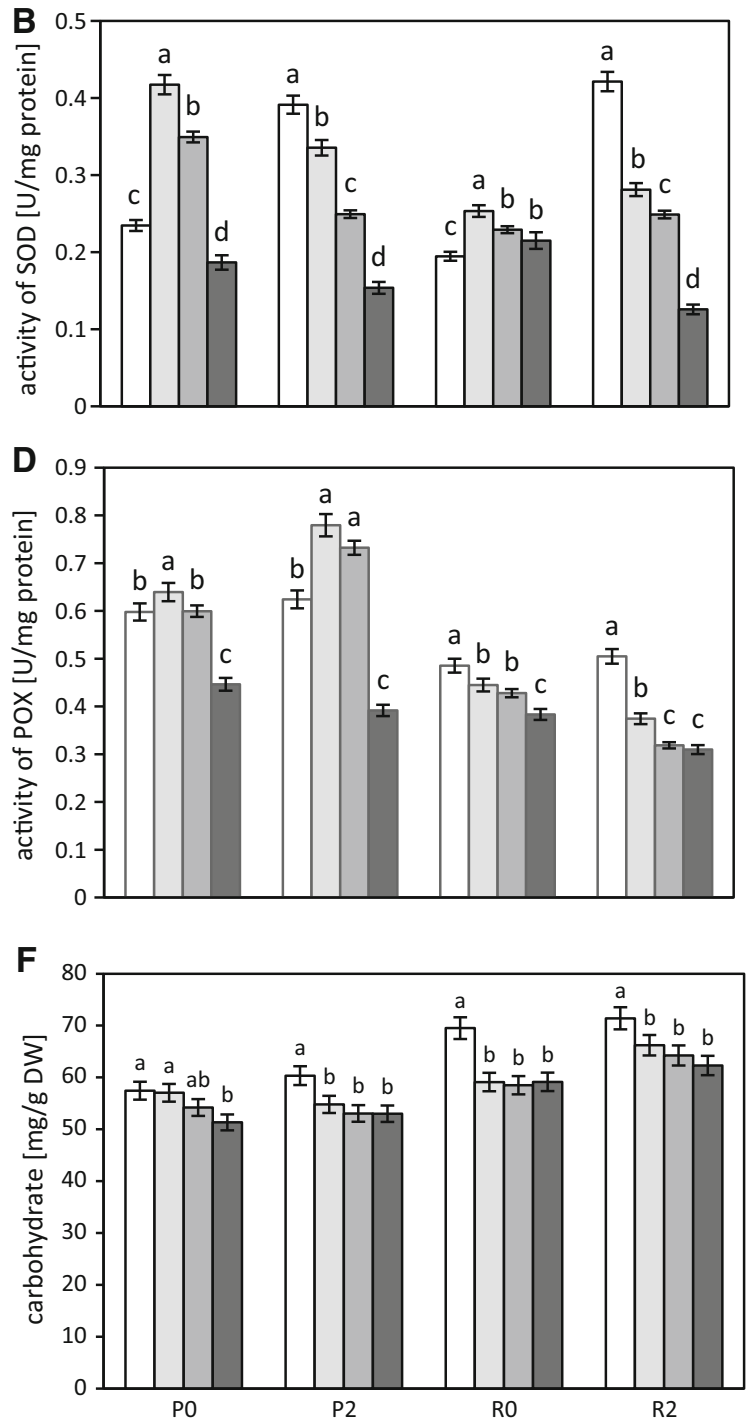

(0) and with 2,4-D (2), and supplemented additionally with $\mathrm{MnSO}_{4}$ at concentrations 0 (control), 1,2 and $3 \mathrm{mM}$. Mean $\pm \mathrm{SE}, n=12$. Significant differences $(p \leq 0.05)$ between Mn doses are indicated by different letters

Table 1 Manganese (Mn) content in calli of wheat cv. Parabola and Raweta cultured in Murashige and Skoog (MS) media without 2,4-D (0) and with 2,4-D (2,4-D), and supplemented additionally with $\mathrm{MnSO}_{4}$ at concentrations: 0 (control), 1, 2 and $3 \mathrm{mM}$

\begin{tabular}{lllll}
\hline Object/MS & \multicolumn{3}{l}{ Mn treatment $(\mathrm{mM})$} & \\
\cline { 2 - 5 } & Control & 1 & $3.88 \pm 0.05^{\mathrm{b}}$ & 3 \\
\hline Parabola 0 & $0.05 \pm 0.01^{\mathrm{d}}$ & $1.71 \pm 0.03^{\mathrm{c}}$ & $3.32 \pm 0.03^{\mathrm{b}}$ & $6.43 \pm 0.05^{\mathrm{a}}$ \\
2,4-D & $0.08 \pm 0.03^{\mathrm{d}}$ & $1.79 \pm 0.03^{\mathrm{c}}$ & $6.10 \pm 0.05^{\mathrm{b}}$ & $6.02 \pm 0.04^{\mathrm{a}}$ \\
Raweta 0 & $0.08 \pm 0.02^{\mathrm{d}}$ & $1.48 \pm 0.02^{\mathrm{c}}$ & $4.73 \pm 0.04^{\mathrm{b}}$ & $6.10 \pm 0.04^{\mathrm{a}}$ \\
2,4-D & $0.09 \pm 0.02^{\mathrm{d}}$ & $2.18 \pm 0.04^{\mathrm{c}}$ & $5.56 \pm 0.05^{\mathrm{a}}$ \\
\hline
\end{tabular}

Mean \pm SE, $n=12$. Significant differences $(p \leq 0.05)$ between Mn doses for each genotype and culture media are indicated by different letters

in greater quantities, while $\mathrm{K}$ and $\mathrm{Ca}$ in smaller amounts than 'Raweta', at the largest level of Mg for both genotypes (Fig. 3). The Na content was higher in 'Parabola' cells and lower in calli cultured on 2,4-D media (Fig. 3f). Under Mn treatment, $\mathrm{S}$ uptake increased with increasing $\mathrm{Mn}$ application for all the investigated cells (Fig. 3c). In 'Parabola' 

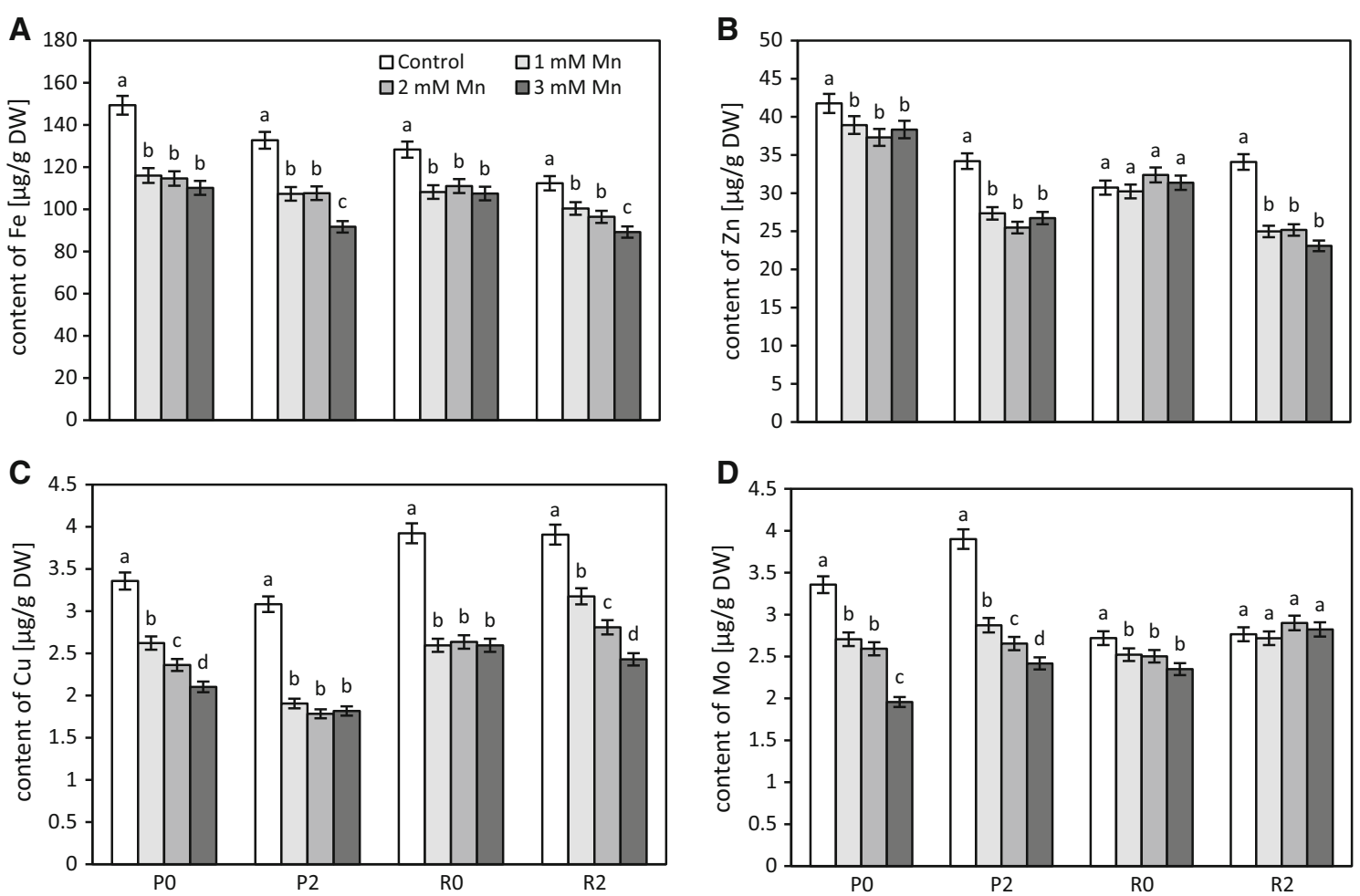

Fig. 2 Iron (Fe; a), zinc ( $\mathrm{Zn}, \mathbf{b})$, copper $(\mathrm{Cu} ; \mathbf{c})$ and molybdenum (Mo; d) content in calli of wheat cv. Parabola (P) and cv. Raweta (R) cultured in Murashige and Skoog media without 2,4-D (0) and with 2,4-D (2), and supplemented additionally with MnSO4 at

calli cultured on MS0 and 2,4-D media, a decrease of $\mathrm{Mg}$ (Fig. 3a), P (Fig. 3d), Ca (Fig. 3e), Na (Fig. 3f) and K (except P2, Fig. 3b) accumulation took place as a result of $\mathrm{Mn}$ application. For 'Raweta' calli, cultured in 2,4-D presence, a decrease of $\mathrm{Ca}$ uptake was observed at all $\mathrm{Mn}$ doses whereas some drop of $\mathrm{P}$ and $\mathrm{Mg}$ accumulation was found but only at $3 \mathrm{mM} \mathrm{Mn}$. In the case of MS0 media, $\mathrm{P}$ accumulation was increased, especially at 1 and $2 \mathrm{mM} \mathrm{Mn}$ doses, while no significant changes (relative to the control) in the accumulation of other macroelements were found.

\section{Discussion}

Wheat calli cultured with/without 2,4-D represent objects of various competence to regeneration and, as indicated in many experiments, the auxin presence stimulates the formation of non-embryogenic cells (Laggner et al. 2003; Filek et al. 2009). Transferring 'Parabola' and 'Raweta' calli from the growth media containing 2,4-D into the media without this hormone and subsequent 7-day culture (control) did not lead to regeneration (Fig. 4) or to the stressogenic response (indicated by changes in MDA content and in antioxidative enzyme activities). The generation of ROS and induction of oxidative stress have been

concentrations: 0 (control), 1,2 and $3 \mathrm{mM}$. Mean \pm SE, $n=12$. Significant differences $(p \leq 0.05)$ between Mn doses are indicated by different letters

suggested as an important step in the mechanism of the regeneration process (de Marco and Roubelakis-Angelakis 1996; Papadakis et al. 2001). As found in our earlier experiments with wheat calli, at least 3-week culturing on MS media (after 2,4-D removing) was necessary to obtain about $15 \%$ regenerates (Filek et al. 2009). In the presented experiments, the time of calli cultivation on media without auxin was probably too short to initiate changes associated with the conversion of cells from non-embryogenic to embryogenic phase; thus the stimulation of antioxidative response was not observed. Comparable values of enzyme activities and MDA content found for tolerant and sensitive genotypes may indicate similarity in the processes of growth of calli on control media, independently of their potential sensitivity to oxidative stress.

Greater differences between the sensitive and tolerant genotypes were found in the carbohydrate contents in cells cultured in control conditions; however, also in this case, no relationships of auxin presence were observed. This confirms our previous suggestion that the 7-day culture on regenerating media was not sufficient to effectively induce the regeneration process. Participation of carbohydrates in changes in osmotic balance in callus cells, followed by differentiation and regeneration processes, was indicated by Blanc et al. (2002). Our results regarding the content of 

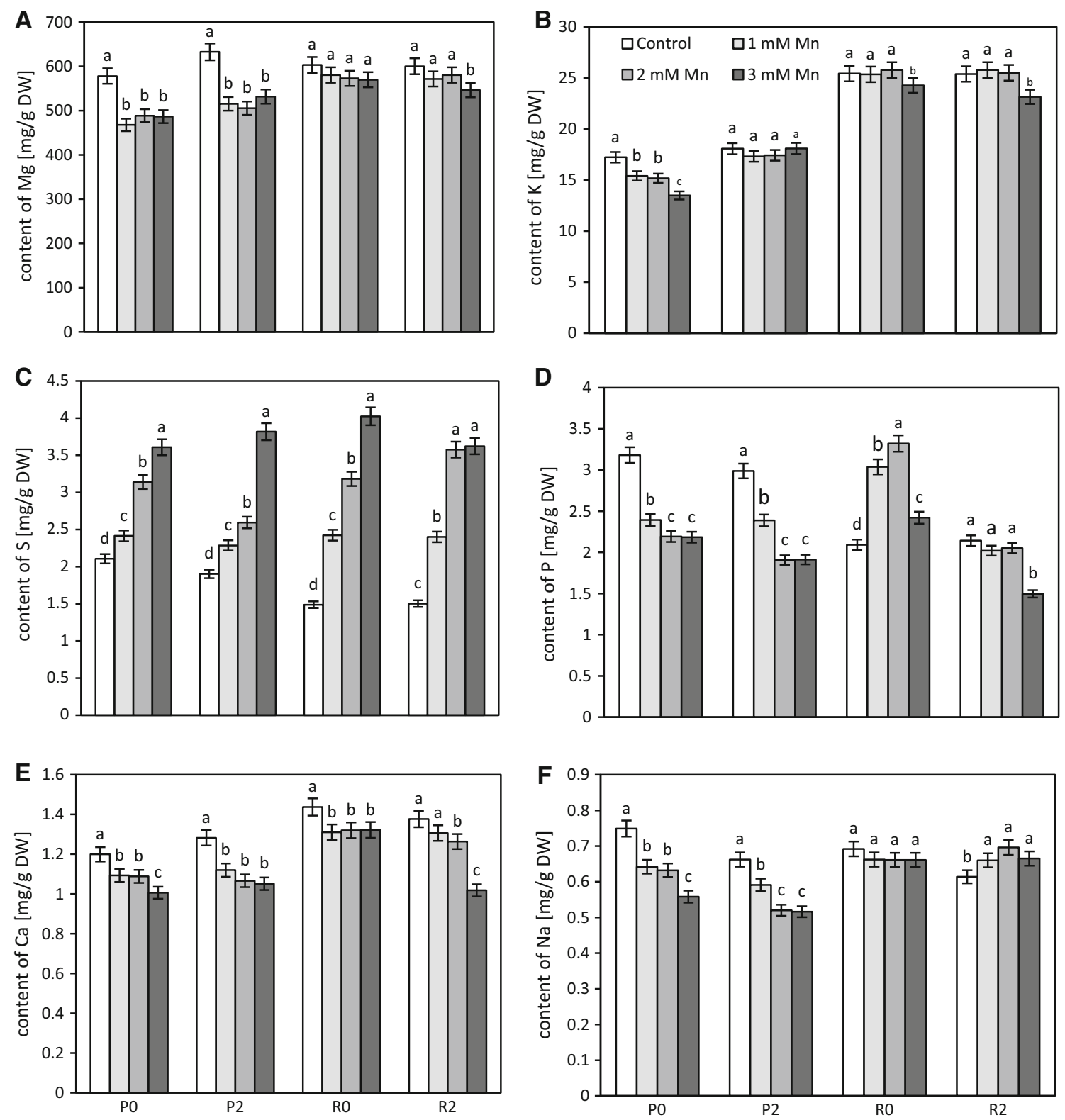

Fig. 3 Magnesium (Mg; a), potassium ( $\mathrm{K} ; \mathbf{b})$, sulfur ( $\mathrm{S}$; c), phosphorus $(\mathrm{P} ; \mathbf{d})$, calcium $(\mathrm{Ca} ; \mathbf{e})$ and sodium $(\mathrm{Na} ; \mathbf{f})$ content in calli of wheat cv. Parabola (P) and cv. Raweta (R) cultured in Murashige and Skoog media without 2,4-D (0) and with 2,4-D (2),

carbohydrates and proline (other substance engaged in osmotic homeostasis) indicated that the levels of these substances in the studied genotypes were different, being higher in the sensitive 'Raweta' cells.

Contrary to the effect of the presence of hormone only, manganese application to the culture media (with/without 2,4-D) stimulated the antioxidative response. When auxin was removed, Mn treatment induced the activity of antioxidant enzymes (SOD, CAT), participating in ROS scavenging, in both sensitive and tolerant genotypes. The stressogenic effect of Mn (manifested as a decrease of SOD

and supplemented additionally with $\mathrm{MnSO} 4$ at concentrations: 0 (control), 1, 2 and $3 \mathrm{mM}$. Mean $\pm \mathrm{SE}, n=12$. Significant differences $(p \leq 0.05)$ between Mn doses are indicated by different letters

and CAT activities) occurred only at the highest Mn doses. Oppositely, auxin inherence seems to increase Mn toxicity (at all used concentrations), as indicated by a decrease in the activity of these enzymes. Interdependence between auxin presence and activation of enzymes in wheat calli has been described in detail by Szechyńska-Hebda et al. (2007). Drop in the activity of antioxidative enzymes under stress action may indicate excessive ROS regeneration, leading to damage of the protein structure of enzymes (Malar et al. 2014). Changes in the activity of antioxidative enzymes suggest that the elimination of auxin from the 

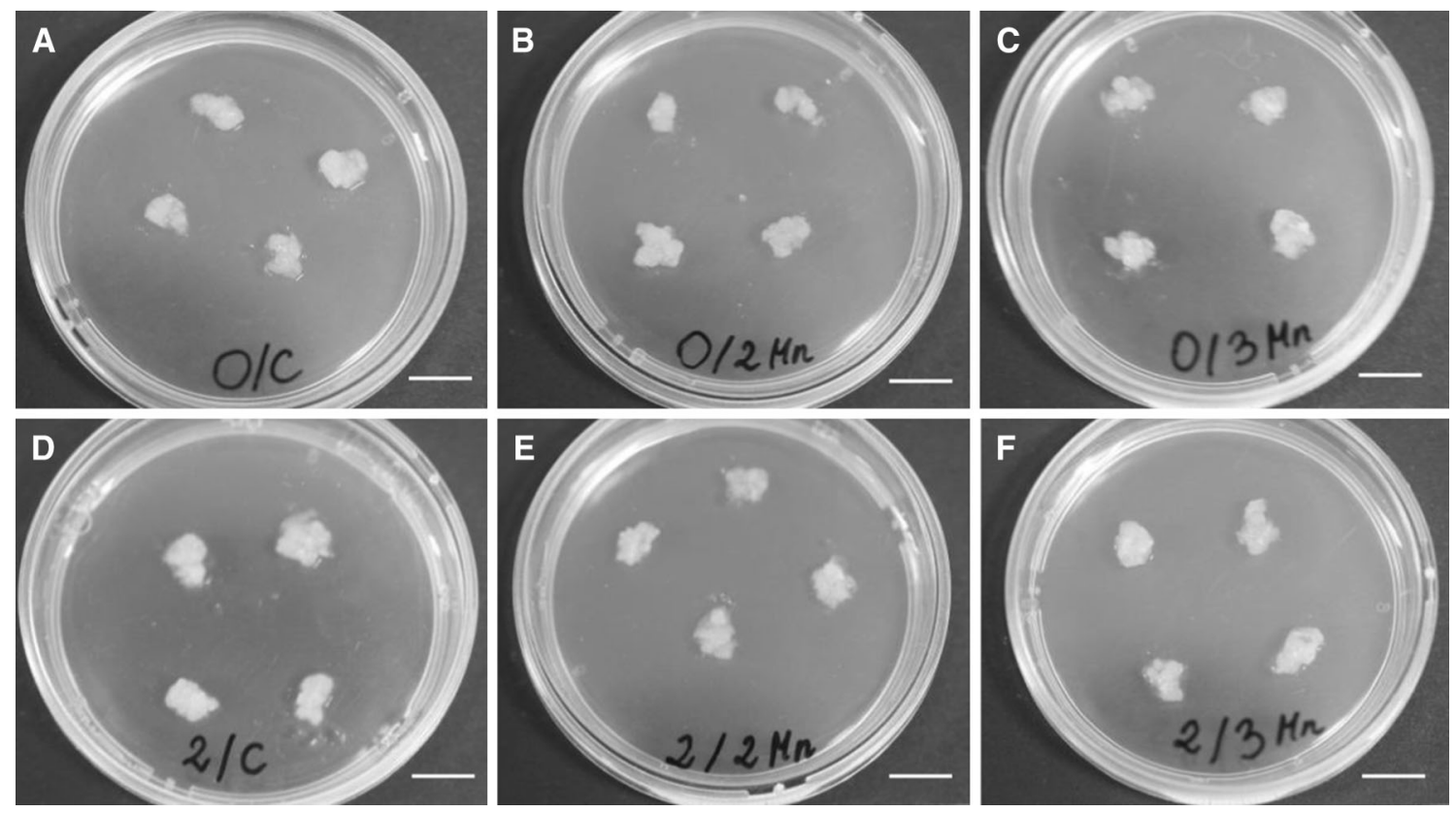

Fig. 4 Photos of wheat calli cv. Raweta cultured (7 days) on Murashige and Skoog media without 2,4-D (0) and with 2,4-D (2)—control (C) and supplemented with $\mathrm{MnSO}_{4}$ at $2 \mathrm{mM} \mathrm{Mn}(2 \mathrm{Mn})$ and $3 \mathrm{mM} \mathrm{Mn}(3 \mathrm{Mn})$. Size bars $10 \mathrm{~mm}$

culture media increased the ability of the cells of both tolerant and sensitive genotypes resistant to Mn stress (at lower 1 and $2 \mathrm{mM}$ Mn doses), by activation of SOD in the reaction of $\mathrm{O}_{2}^{--}$to less toxic $\mathrm{H}_{2} \mathrm{O}_{2}$ (Mates 2000; Zhao et al. 2012), followed by CAT activation in the conversion of $\mathrm{H}_{2} \mathrm{O}_{2}$ to water (Kar 2011).

The activity of POX, more than of other enzymes, seems to be genotype dependent. POX isoforms are involved not only in the antioxidative response under $\mathrm{H}_{2} \mathrm{O}_{2}$ generation, but also in essential morphological processes, such as cell wall modifications or protoplast regeneration (Papadakis and Roubelakis-Angelakis 2002). The reduction of POX activity at all Mn treatments in both media (with/without 2,4-D) in the stress-sensitive 'Raweta' calli may indicate that even the lowest $\mathrm{Mn}$ concentration may stimulate damage of the POX-enzyme structure in this genotype. In the tolerant 'Parabola' cells, a decrease of POX activity occurred only at the highest Mn dose. Thus, changes in the activity of this group of enzymes may be a specific indicator of wheat cell tolerance to Mn stress.

The differences in the formation of ROS in the cells of both wheat genotypes in Mn presence in media were confirmed by the determination of MDA concentrations. An increase in MDA content results from the peroxidation of chains of unsaturated fatty acids by excess of ROS occurrence in cell membranes, and thus it can serve as an indicator of the oxidative stress activation (Sharma et al. 2012). Increased MDA content, found under Mn application, led to the assumption that 'Raweta' cells, for which a noticeable increase of lipid peroxidation was observed (especially in media with 2,4-D), were more sensitive to Mn stress than 'Parabola' cells, and that removing of auxin from the culture media may partly decrease the toxic action of $\mathrm{Mn}$.

Changes of proline content in calli of tolerant and sensitive genotypes under $\mathrm{Mn}$ stress pointed to the involvement of osmotic mechanisms in the cells of the sensitive genotype. An increased amount of this substance may be associated with maintaining osmotic balance under conditions of water deficit (at increased Mn accumulation) in cells (Man et al. 2011) and it proves that Mn presence may initiate drought stress in cells (Yao et al. 2012). However, carbohydrates seem not to be involved in osmotic protection. The observed decrease of carbohydrate concentrations may result from the perturbation of their biosynthesis under excess of $\mathrm{Mn}$ in cells. Smaller changes of the contents of these substances in 'Parabola' calli may be due to the less disorder caused by $\mathrm{Mn}$ in the tolerant genotype.

Considering the demonstrated differences in concentrations/activities of antioxidants in 'Parabola' and 'Raweta' cells, it can be assumed that the variation of selected wheat genotypes, in relation to drought stress resistance, also refers to its resistance to excess manganese.

The accumulation of $\mathrm{Mn}$ in control calli was at a similar level as found for embryos isolated from grains of investigated plants with higher accumulation found in embryos of tolerant genotypes (Sieprawska et al. 2014). Different relationships established for calli and embryos were probably connected with the environmental conditions, in which callus cells and plants (from which embryos were isolated) were cultured. 
Breeding of calli on MS media provides optimal (for crops) concentrations of all macro- and microelements (including Mn ions) (Murashige and Skoog 1962). A similar Mn level observed for all control cells can be a good reference point to compare the effects of toxic $\mathrm{Mn}$ doses on the level of this element. Callus cells may offer a good model for estimating the impact of Mn stress on the permeability of the membranes for this element (in cationic form) in cells of both sensitive and tolerant wheat.

Smaller Mn uptake by tolerant 'Parabola' cells (at 1 and $2 \mathrm{mM} \mathrm{Mn}$ ) (in comparison to the cells of sensitive genotype) may be explained by a lower membrane permeability, similarly as it was found in the leaves. However, the lack of correlation between membrane lipid saturation (expressed by MDA increase) and $\mathrm{Mn}$ accumulation indicates that other mechanisms are rather involved in this element transport to cells. The $3 \mathrm{mM}$ Mn level in media seems to be the maximum tolerable concentration of this element for wheat cells, since the similarity of Mn uptake in the calli of both types of genotypes indicated possible destruction of protective mechanisms in the tolerant genotype.
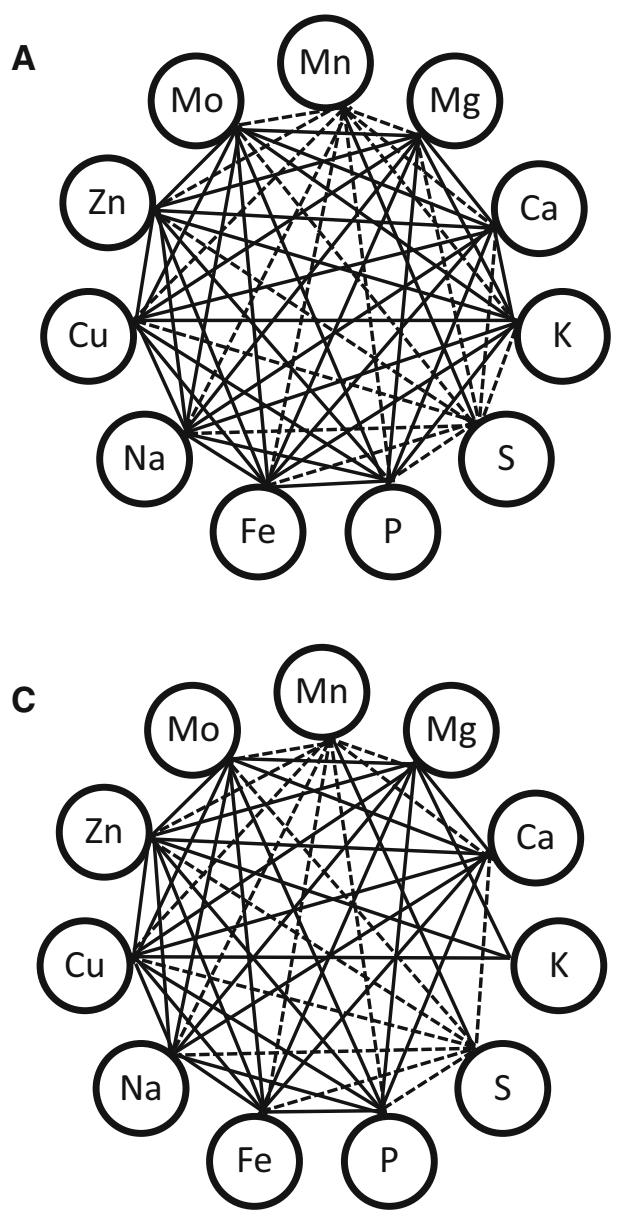

Fig. 5 Correlations between the elements contained in calli of wheat cv. Parabola (P) and cv. Raweta (R) cultured in Murashige and Skoog media without 2,4-D (0) and with 2,4-D (2), supplemented
The calculation of the correlation between the uptake of Mn and other micro- and macroelements, and the analysis of biplot allowed to infer quantitative relationships in the accumulation of elements important for the proper functioning of cells. The obtained relationships provide new data on the knowledge of Mn toxicity mechanism, which is still not fully understood.

The progressive increase of $\mathrm{S}$ accumulation in all calli, correlating with Mn concentration in the media $(r=0.97$, $p<0.05$ ), may be regarded as additional delivery of $\mathrm{S}$ ions in $\mathrm{MnSO}_{4}$ presence. Similar dependence between $\mathrm{S}$ and $\mathrm{Mn}$ accumulation was found by Ashok et al. (2009). In relation to the rest of the analyzed elements, in 'Parabola' cells, only negative correlations with $\mathrm{Mn}$ supplementation were found. Therefore, it can be assumed that Mn uptake is associated with a decrease in the accumulation of those elements. However, some positive correlations (Mn with $\mathrm{Zn}$ on 0 media and $\mathrm{Mn}$ with $\mathrm{Mo}$ and $\mathrm{Na}$ on 2,4-D media) were detected in 'Raweta' cells, indicating their elevated absorption in the presence of Mn (Fig. 5). Negative correlations between $\mathrm{Mn}$ and $\mathrm{Fe}, \mathrm{Zn}, \mathrm{Cu}$ and $\mathrm{Ca}$ were
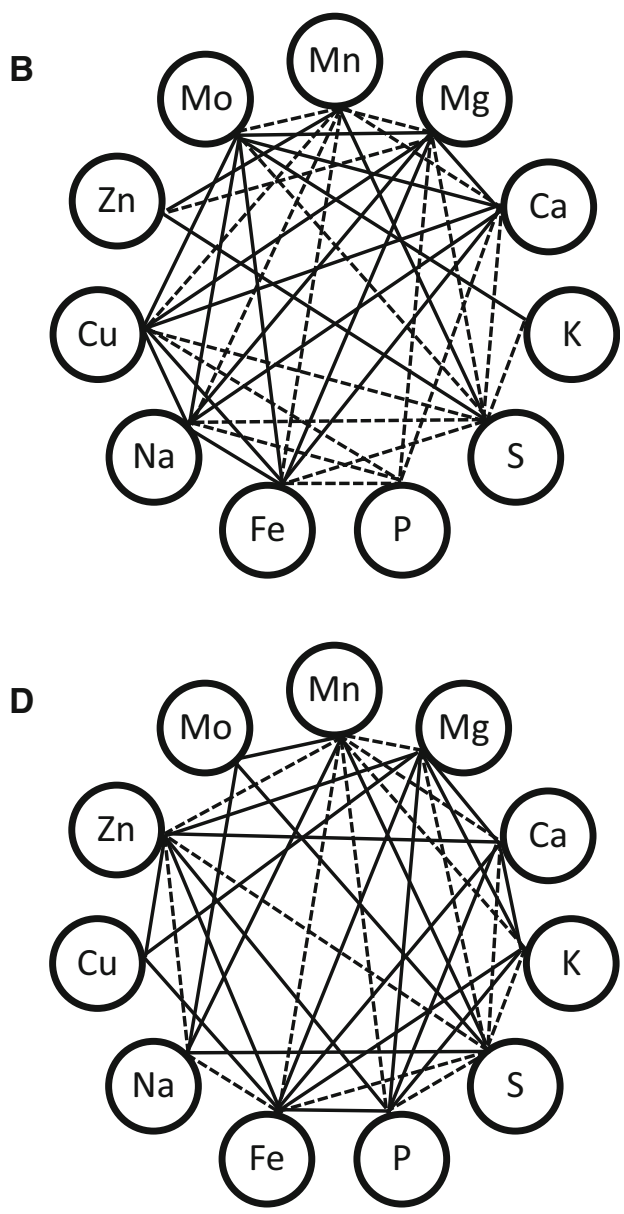

additionally with $\mathrm{MnSO}_{4}$. Solid lines represent positive correlation values; dashed lines represent negative correlation values $(p<0.05)$. a P0, b R0, c P2, d R2 


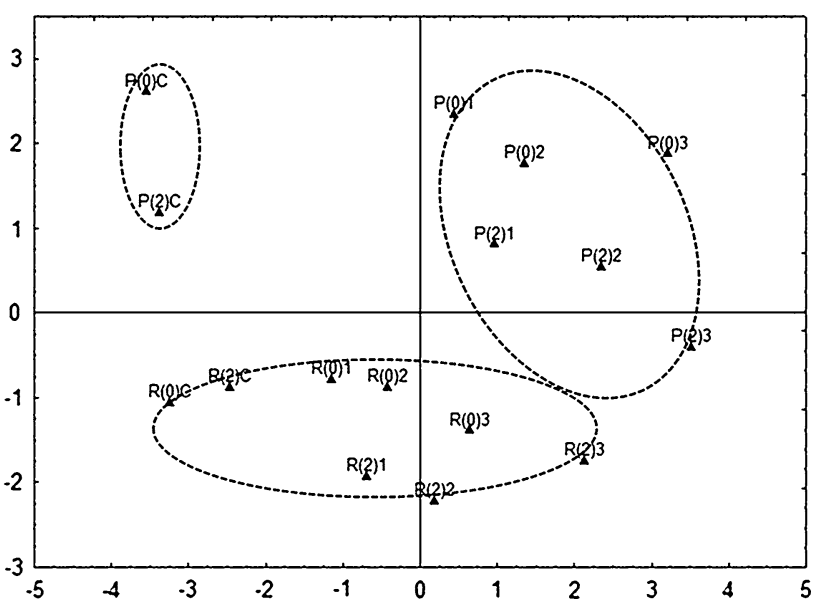

Fig. 6 Biplot analysis of the relationship between concentrations of micro- and macroelements in calli of wheat cv. Parabola (P) and cv. Raweta (R) cultured in Murashige and Skoog media without 2,4-D (0) and with 2,4-D (2), supplemented additionally with $\mathrm{MnSO}_{4}$ at doses: 0 (C), 1(1), 2 (2) and 3 (3) $\mathrm{mM}$. Ellipses represent the region of confidence covering $95 \%$ of the data

expected, since transporters of these elements are also exploited by Mn (Cohen et al. 1998; Xia et al. 2010). The positive correlation between $\mathrm{Mn}$ and $\mathrm{Zn}$ in case of sensitive genotype cultured on media with removed auxin may be the result of a potential increase of the antioxidative protection during future regeneration processes. The introduction of $\mathrm{Zn}$ to cells could stimulate the enlargement of the pool of antioxidative enzymes.

Generally, higher number of correlations (mainly positive) between the all (except of Mn) absorbed elements, modified by Mn treatment, were observed for 'Parabola' calli, especially in the MS0 media (Fig. 5a). Thus, it seems that $\mathrm{Mn}$ presence in the cells of tolerant genotype, by stimulating the other elements uptake, may create a composition of nutrients in the environment promoting mechanisms diminishing the Mn-induced stressogenic effects. It is worth noticing that a higher content of such microelements as $\mathrm{Fe}, \mathrm{Zn}$ and $\mathrm{Cu}$ (present as the components of antioxidant enzymes) (Nagajyoti et al. 2010; Kamiński et al. 2012), which characterized the 'Parabola' calli, may be also an important factor in their better response to oxidative stress caused by Mn.

The biplot of relationships between the concentrations of all elements (micro- and macroelements) and different Mn doses in the media confirmed the suggested differences in the sensitivity/tolerance of the investigated genotypes to excess of Mn (Fig. 6). On the basis of various locations of points in the I and II quarter of the graph, it could be concluded that elements' accumulation in the tolerant genotype is dependent on 2,4-D presence in the media and is different for the control and that under Mn treatment. For cells of sensitive genotype, weaker dependence on auxin presence occurred; however, the position of points in the IV quarter of the biplot indicates that the elements may be specifically absorbed at the highest used Mn doses.

\section{Conclusion}

Research carried out on model systems of callus cells under controlled conditions in vitro allowed to demonstrate differences in the reactions of tolerant and sensitive wheat genotypes to Mn excess. Cell susceptibility to Mn stress seems to be related to disorders of osmotic conditions, as indicated by increased synthesis of proline in the sensitive variety. On the basis of the experiments involving antioxidant response and analyses of trace elements' uptake, it is suggested that the consequence of high doses of $\mathrm{Mn}$ accumulation is increased ROS generation observed as elevated lipid peroxidation and activation of antioxidant enzymes. The presence of auxin may reduce the tolerance to oxidative stress in the sensitive genotype. Doses of up to $2 \mathrm{mM} \mathrm{Mn}$ do not create toxic conditions for the tolerant genotype, which had reduced ability to accumulate this metal. Therefore, it can be concluded that the intensity of Mn stress in wheat is dependent on the amount of this element accumulated in the cells. The increase of $\mathrm{Mn}$ uptake is accompanied by a reduction of transport of other important micro- and macroelements, simultaneously affecting the relationships between them.

Author contribution statement AS, MF and AT designed the research; AT, SW, DD-A, EG-S and AS conducted the research; AS and MF analyzed the data; AS wrote the paper; AS had primary responsibility for the final content. All authors have read and approved the final manuscript.

Acknowledgments This work was supported by a Grant from the National Science Center, Poland, Project no. 2013/11/D/ST4/02839.

Open Access This article is distributed under the terms of the Creative Commons Attribution 4.0 International License (http://crea tivecommons.org/licenses/by/4.0/), which permits unrestricted use, distribution, and reproduction in any medium, provided you give appropriate credit to the original author(s) and the source, provide a link to the Creative Commons license, and indicate if changes were made.

\section{References}

Aebi H (1984) Catalase in vitro. Method Enzym 105:121-126 Alam S, Kamei S, Kawai S (2001) Amelioration of manganese toxicity in barley with iron. J Plant Nutr 28:1421-1433

Alam S, Akiha F, Kamei S, Huq S, Kawai S (2005) Mechanism of potassium alleviation of manganese phytotoxicity in barley. J Plant Nutr 28:889-901 
Alam S, Kodama R, Akiha F, Kamei S, Kawai S (2006) Alleviation of manganese phytotoxicity in barley with calcium. J Plant Nutr 29:59-74

Alloway BJ (2008) Micronutrients and crop production: an introduction. In: Alloway BJ (ed) Micronutrient deficiencies in global crop production. Springer, Berlin, pp 1-40

Ashok JS, Kumar P, Chauhan N, Singh GR (2009) Effect of the levels of potassium and manganese on the uptake of $\mathrm{N}, \mathrm{P}$, and $\mathrm{K}$ and yield of wheat. J Agric Phys 9:28-32

Babitha MP, Bhat SG, Prakash HS, Shetty HS (2002) Differential induction of superoxide dismutase in downy mildew-resistant and -susceptible genotypes of pearl millet. Plant Pathol 51:480-486

Bates L, Waldren RP, Teare ID (1973) Rapid determination of free proline for water-stress studies. Plant Soil 39:205-207

Blanc G, Lardet L, Martin A, Jacob JL, Carron MP (2002) Differential carbohydrate metabolism conducts morphogenesis in embryogenic callus of Hevea brasiliensis (Müll. Arg.). J Exp Bot 53:1453-1462

Boojar MMA, Goodarzi F (2008) Comparative evaluation of oxidative stress status and manganese availability in plants growing on manganese mine. Ecotox Environ Safe 71:692-699

Chen L-S, Qi Y-P, Liu X-H (2005) Effects of aluminum on light energy utilization and photoprotective systems in citrus leaves. Ann Bot 96:35-41

Cohen CK, Fox TC, Garvin DF, Kochian LV (1998) The role of iron deficiency stress responses in stimulating heavy-metal transport in plants. Plant Physiol 116:1063-1072

de Marco A, Roubelakis-Angelakis KA (1996) Hydrogen peroxide plays a bivalent role in the regeneration of protoplasts. J Plant Physiol 149:109-114

Demirevska-Kepova K, Simova-Stoilova L, Stoyanova Z, Holzer R, Feller U (2004) Biochemical changes in barley plants after excessive supply of copper and manganese. Environ Exp Bot 52:253-266

Dhindsa RS, Plumb-Dhindsa P, Thorpe TA (1981) Leaf senescence: correlated with increased levels of membrane permeability and lipid peroxidation, and decreased levels of superoxide dismutase and catalase. J Exp Bot 32:93-101

Elstner EF, Wagner GA, Schütz W (1988) Activated oxygen in green plants in relation to stress situation. Curr Top Plant Biochem Physiol 7:159-187

Fecht-Christoffers MM, Maier P, Horst WJ (2003) Apoplastic peroxidases and ascorbate are involved in manganese toxicity and tolerance of Vigna unguiculata. Physol Plant 117:237-244

Filek M, Zembala M, Hartikainen H, Miszalski Z, Kornaś A, Wietecka-Posłuszny R (2009) Changes in wheat plastid membrane properties induced by cadmium and selenium in presence/ absence of 2,4-dichlorophenoxyacetic acid. Plant Cell Tiss Organ Cult 96:19-28

Filek M, Walas S, Mrowiec H, Rudolphi-Skórska E, Sieprawska A, Biesaga-Kościelniak J (2012) Membrane permeability and micro- and macroelement accumulation in spring wheat cultivars during the short-term effect of salinity- and PEG-induced water stress. Acta Physiol Plant 34:985-995

Grzesiak M, Filek M, Barbasz A, Kreczmer B, Hartikainen H (2013) Relationships between polyamines, ethylene, osmoprotectants and antioxidant enzymes activities in wheat seedlings after shortterm PEG- and NaCl-induced stresses. Plant Growth Regul 69:177-189

Hare PD, Cress WA (1997) Metabolic implications of stress-induced proline accumulation in plants. Plant Growth Regul 21:79-102

Janeczko A, Biesaga-Kościelniak J, Oklešt'ková J, Filek M, Dziurka M, Szarek-Łukaszewska G, Kościelniak J (2010) Role of 24-epibrassinolide in wheat production: physiological effects and uptake. J Agron Crop Sci 196:311-321
Kamiński P, Koim-Puchowska B, Puchowski P, Jerzak L, Wieloch M, Bombolewska K (2012) Enzymatic antioxidant responses of plants in saline anthropogenic environments. InTech, pp 35-64. http://dx.doi.org/10.5772/51149

Kar RK (2011) Plant responses to water stress: role of reactive oxygen species. Plant Signal Behav 6:1741-1745

Łabanowska M, Filek M, Kurdziel M, Bidzinska E, Miszalski Z, Hartikainen H (2013) EPR spectroscopy as a tool for investigation of differences in radical status in wheat plants of various tolerances to osmotic stress induced by $\mathrm{NaCl}$ and PEGtreatment. J Plant Physiol 170:136-145

Laggner P, Filek M, Marcinska I, Szechyńska-Hebda M, Kriechbaum M (2003) X-ray structure investigations of winter wheat membrane systems. I. Influence of phytohormones on phospholipid orientation in non- and embryogenic cells. Plant Sci 165:265-270

Lei Y, Korpelainen H, Li C (2007) Physiological and biochemical responses to high Mn concentrations in two contrasting Populus cathayana populations. Chemosphere 68:686-694

Lück H (1965) Catalase. In: Bergmeyer HU (ed) Methods of enzymatic analysis. Academic Press, New York, pp 885-888

Lynch JP, St Clair SB (2004) Mineral stress: the missing link in understanding how global climate change will affect plants in real world soils. Field Crops Res 90:101-115

Malar S, Vikram SS, Favas PJC, Perumal V (2014) Lead heavy metal toxicity induced changes on growth and antioxidative enzymes level in water hyacinths [Eichhornia crassipes (Mart.)]. Bot Stud 55:54. doi:10.1186/s40529-014-0054-6

Man D, Yong-Xia Bao YX, Han LB, Zhang X (2011) Drought tolerance associated with proline and hormone metabolism in two tall fescue cultivars. HortScience 46:1027-1032

Marcińska I, Czyczyło-Mysza I, Skrzypek E, Filek M, Grzesiak S, Grzesiak MT, Janowiak F, Hura T, Dziurka M, Dziurka K, Nowakowska A, Quarrie SA (2013) Impact of osmotic stress on physiological and biochemical characteristics in drought-susceptible and drought-resistant wheat genotypes. Acta Physiol Plant 35:451-461

Marschner P (2012) Marschner's mineral nutrition of higher plants. Academic Press, Boston, pp 324-333

Mates M (2000) Effects of antioxidant enzymes in the molecular control of reactive oxygen species toxicology. Toxicology 153:83-104

McCord JM, Fridovich I (1969) Superoxide dismutase: an enzymic function for erythrocuprein (hemocuprein). J Biol Chem 244:6049-6055

Merchant S, Sawaya MR (2005) The light reactions: a guide to recent acquisitions for the picture gallery. Plant Cell 17:648-663

Migocka M, Klobus G (2007) The properties of the Mn, Ni and Pb transport operating at plasma membranes of cucumber roots. Physiol Plant 129:578-587

Millaleo R, Reyes-Diaz M, Ivanov AG, Mora ML, Alberdi M (2010) Manganese as essential and toxic element for plants: transport, accumulation and resistance mechanisms. J Soil Sci Plant Nutr 10:470-481

Millaleo R, Reyes-Diaz M, Alberdi M, Ivanov AG, Krol M, Huner NP (2013) Excess manganese differentially inhibits photosystem I versus II in Arabidopsis thaliana. J Exp Bot 64:343-354

Mohammadkhani N, Heidari R (2008) Drought-induced accumulation of soluble sugars and proline in two maize varieties. World Appl Sci J 13:448-453

Mora M, Rosas A, Ribera A, Rengel R (2009) Differential tolerance to $\mathrm{Mn}$ toxicity in perennial ryegrass genotypes: involvement of antioxidative enzymes and root exudation of carboxylates. Plant Soil 253:507-519

Murashige T, Skoog FA (1962) A revised medium for a rapid growth and bioassays with tobacco tissues cultures. Plant Physiol $15: 473-479$ 
Nagajyoti PC, Lee KD, Sreekanth TVM (2010) Heavy metals, occurrence and toxicity for plants: a review. Environ Chem Lett 8:199-216

Papadakis AK, Roubelakis-Angelakis KA (2002) Oxidative stress could be responsible for the recalcitrance of plant protoplast. Plant Phys Biochem 40:549-559

Papadakis AI, Siminis CI, Roubelakis-Angelakis KA (2001) Reduced activity of antioxidant machinery is correlated with supression of totipotency in plant protoplasts. Plant Physiol 126:434-444

Perveen S, Shahbaz M, Ashraf M (2011) Modulation in activities of antioxidant enzymes in salt stressed and non-stressed wheat (Triticum aestivum L.) plants raised from seed trearted with triacontanal. Pak J Bot 43:2463-2468

Pittman JK (2005) Managing the manganese: molecular mechanisms of manganese transport and homeostasis. New Phytol 167:733-742

Reeves RD (2006) Hyperaccumulation of trace elements by plants. In: Morel JL, Echevarria G, Goncharova N (eds) Phytoremediation of metal-contaminated soils. Springer, Berlin, pp 25-52

Rengel Z (2000) Manganese uptake and transport in plants. Met Ions Biol Syst 37:57-87

Rosas A, Rengel Z, Mora M (2007) Manganese supply and pH influence growth, carboxylate exudation and peroxidase activity of ryegrass and white clover. J Plant Nutr 30:253-270

Santandrea G, Schiff S, Bennici A (1997) Manganese toxicity to different growth processes in vitro in Nicotiana. Plant Cell Tiss Org Cult 50:125-129

Santandrea G, Schiff S, Bennici A (1998) Effects of manganese on Nicotiana species cultivated in vitro and characterization of regenerated Mn-tolerant tobaccoplants. Plant Sci 132:71-82

Seresinhe PSJW (1996) The effect of manganese on the growth of tomato cells in suspension culture. J Natn Sci Coun Sri Lanka 24:267-278

Sharma P, Jha AB, Dubey RS, Pessarakli M (2012) Reactive oxygen species, oxidative damage, and antioxidative defense mechanism in plants under stressful conditions. J Bot. doi:10.1155/2012/ 217037 (article ID 217037)

Shi Q-H, Zhu Z-J, Li J, Qian Q-Q (2006) Combined effects of excess $\mathrm{Mn}$ and low $\mathrm{pH}$ on oxidative stress and antioxidant enzymes in cucumber roots. Agric Sci China 5:767-772
Sieprawska A, Filek M, Walas S, Tobiasz A, Mrowiec H, Miszalski Z (2014) Does micro- and macroelement content differentiate grains of sensitive and tolerant wheat varieties? Acta Physiol Plant 36:3095-3100

Socha AL, Guerinot ML (2014) Mn-euvering manganese: the role of transporter gene family members in manganese uptake and mobilization in plants. Front Plant Sci 5:article 106. doi:10.3389/ fpls.2014.00106

Szechyńska-Hebda M, Skrzypek E, Dąbrowska G, Biesaga-Kościelniak J, Filek M, Wędzony M (2007) The role of oxidative stress induced by growth regulators in the regeneration process of wheat. Acta Physiol Plant 29:327-337

Taulavuori E, Hellström EK, Taulavuori K, Laine K (2001) Comparison of two methods used to analyse lipid peroxidation from Vaccinium myrtillus (L.) during snow removal, reacclimation and cold acclimation. J Exp Bot 52:2375-2380

Tobiasz A, Walas S, Filek M, Mrowiec H, Samsel K, Sieprawska A, Hartikainen H (2014) Evaluation of selenium effect on microand macroelements distribution to different wheat tissues during principal plant development stages. Biol Plant 58:370-374

Todorović S, Giba Z, Simonović A, Božić D, Banjanc T, Grubišić D (2009) Manganese effects on in vitro development of lesser centaury [Centaurium pulchellum (Sw.) Druce]. Arch Biol Sci 61:279-283

Upadhyaya H, Sahoo L, Panda SK (2013) Molecular physiology of osmotic stress in plants. In: Rout GR, Das AB (eds) Molecular stress physiology of plants. Springer, Berlin, pp 179-192

Xia J, Yamaji N, Kasai T, Ma JF (2010) Plasma membrane-localized transporter for aluminum in rice. Proc Natl Acad Sci USA 107:18381-18385

Yao Y, Xu G, Mou D, Wang J, Ma J (2012) Subcellular Mn compartation, anatomic and biochemical changes of two grape varieties in response to excess manganese. Chemosphere 892:150-157

Zhao H, Wu L, Chai T, Zhang Y, Tan J, Ma S (2012) The effects of copper, manganese and zinc on plant growth and elemental accumulation in the manganese-hyperaccumulator Phytolacca americana. J Plant Physiol 169:1243-1252 